\title{
Effect of Water Hyacinth (Eichhornia Crassipes (Mart) Solms Leaf Extract on the Juvenile Mortality of Meloidogyne Incognita
}

\author{
*I. Umar and Mohammed, B. A \\ Department of Crop Protection Modibbo Adama University of Technology, Yola
}

\begin{abstract}
The effect of extract of water hyacinth leaves extract was investigated on the juvenile mortality of Meloidogyne incognita in the laboratory. M. incognita juveniles (100 Juveniles in each Petri dish) were exposed to crude extract $-100 \%$ concentration, crude extract $+10 \mathrm{ml}$ of distilled water and crude extract $+20 \mathrm{ml}$ distilled water, and distilled water only which served as control. Petri dishes were arranged in completely randomized design in the laboratory. Percentage mortality was calculated over 96 hours. Results indicated that the crude extracts gave $100 \%$ juvenile mortality. The results also indicated that juvenile mortality increased with increase in time of exposure. It would be concluded that the extract was able to killed M. incognita juveniles in the laboratory, however, further screen house and field trials are recommended.
\end{abstract}

Key Words: Water hyacinth, extract, juvenile, mortality, concentration

\section{Introduction}

Eichhornia crassipes (Mart) Solms commonly known as Water hyacinth is a warm water aquatic plant belonging to the family Pontideraceae. It is listed as one of the most productive plant on earth and is considered the world worst aquatic weed (Grodowitz, 1998). The 'beautiful blue devil', water hyacinth is recognised by its lavender flowers and shinning bright leaves which spread at an alarming rate. Its habitat ranges from tropical desert to subtropical or warm temperate rain forest zones, and tolerates a temperature range of 21.1 to $27.2^{0} \mathrm{C}$ (Lata and Venapani, 2010). It can be used as compost, paper, fuel, and animal feed and water purification (Kristie, 2012). It is also an excellent source of biomass; and use to make furniture, hand bags and ropes in East Africa. Its flowers are used as a medication on skin of horses and a tonic (Wikipedia, 2012). It is also found to be effective in controlling microorganisms such as fungi and bacterial diseases in plants and humans because of its phytochemical compounds (Lata and Venapani, 2010) .

Meloidogyne incognita caused particularly severe yield losses, typically up to $50 \%$ (Darekar andMhase, 1988) as a result of root deformation which diminishes function and predisposes plants to other pathogens (Natarajar et al., 2006). Meloidogyne spp are notoriously difficult to control because of their wide host range and high rates of reproduction with many generation times in a season (Ploeg, 2002).

Synthetic nematicides are expensive and highly toxic to humans, beneficial organisms and environment (Umar, 2009). Although, they have been found to increase crop yields (IITA, 2000), they are still a problem to the environment. There is, therefore, the need to develop alternatives to synthetic nematicides that are effective, ecologically safe and economical to peasant farmers ( Yudelman. et al., 1998, Atungwu, et al., 2009).

The use of botanicals has been suggested as an alternative to chemical nematicides. These botanicals are effective, safe, cheap and available to farmers (Adegbite and Adesiyan, 2005, Javed, et al., 2007). This study was aimed at investigating different levels of leaves extract of water hyacinth on juvenile mortality of M.incognita in the laboratory.

\section{Experimental site}

\section{Materials And Methods}

The experiment was conducted in the laboratory of the Department of Crop Protection, Modibbo Adama University of Technology, Yola, Adamawa state, Nigeria, in July 2010. Yola is located within latitude $9^{0}$ and $9^{1} \mathrm{~N}$ and longitude $12^{0} 30^{1} \mathrm{E}$, at an altitude of $185.9 \mathrm{~m}$ above sea level (Bashir, 2000).

\section{Preparation of extract}

Water hyacinth leaves were collected from water bodies around the university. The fresh leaves after collection were washed with water and shade dried for seven (7) days on polythene sheets. The dried material was then pounded into powder with pestle and mortar. Five hundred grams of powdered sample was poured into $100 \mathrm{ml}$ conical flask, distilled water was added and the set up was allowed to stand for 24 hrs before it was centrifuged at $500 \mathrm{rpm}$ and filtered through Whatman no. 42 filter paper (Rao et al., 1998). The filtrate so obtained was designated as crude extract (C), and this was diluted with 10 and $20 \mathrm{ml}$ of distilled water to give concentrations $\mathrm{C}_{1}$ and $\mathrm{C}_{2}$ respectively. Distilled water was used as control. 


\section{Phytochemical analysis of the plant extract}

Phytochemical analysis of the plant extract for tannins, saponins, alkaloid, flavonoid, phenol and quinones was carried out in the laboratory using the methods described by Sofowora (1993) and Trease and Evans (1989).

\section{Extraction of M. incognita juveniles}

M. incognita maintained on galled tomato roots were extracted for the experiment using the modified Bearmamn funnel method (Whitehead and Hemming, 1965).

\section{Effect of extract on juvenile mortality}

Ten (10) mls of the crude extract and the diluted forms were separately dispensed into petri dishes and $2 \mathrm{ml}$ of suspensions containing 100 juveniles of $\mathrm{M}$. incognita was introduced into each of the petri dishes with a syringe. Ten petri dishes were used for each treatment. Petri dishes for control contained only distilled water, (no extract). Each treatment was replicated three times. Petri dishes were arranged in completely randomised design in the laboratory. Mean percentage mortality was collected over a period of $96 \mathrm{hrs}$.

\section{Results And Discussion}

The result of the phytochemical analysis of the extract indicated the presence of alkaloid, tannins, flavonoid and phenolic compounds. The extract contained no saponin (Table 1). The results on juvenile mortality showed that the crude extract gave $100 \%$ mortality of $\mathrm{M}$. incognita larvae in all the exposure periods (Figure 1). The diluted extract $\left(\mathrm{C}_{1}\right)$ gave juvenile mortality of $56.1 \%$ at $24 \mathrm{hrs}$ exposure and increased up to $80.7 \%$ at $96 \mathrm{hrs}$ exposure. The results further showed that the higher the concentration of the extract and exposure time, the higher the larval mortality. The presence of phytochemicals such as alkaloid and flavonoid in the extract could have been responsible for the mortality of juveniles. The results of this study

Table 1: Phytochemical analysis of the plant material

\begin{tabular}{ll}
\hline Phytochemical & \\
\hline Tannin & ++ \\
Alkaloid & ++ \\
Flavonoid & ++ \\
Phenolic compounds & ++ \\
Saponins & -- \\
& \\
\hline + presence of photochemical, - absence of photochemical
\end{tabular}

Figure 1: Means of different concentrations of Water hyacinth Extract on Juvenile Mortality of M. Incognita in the laboratory

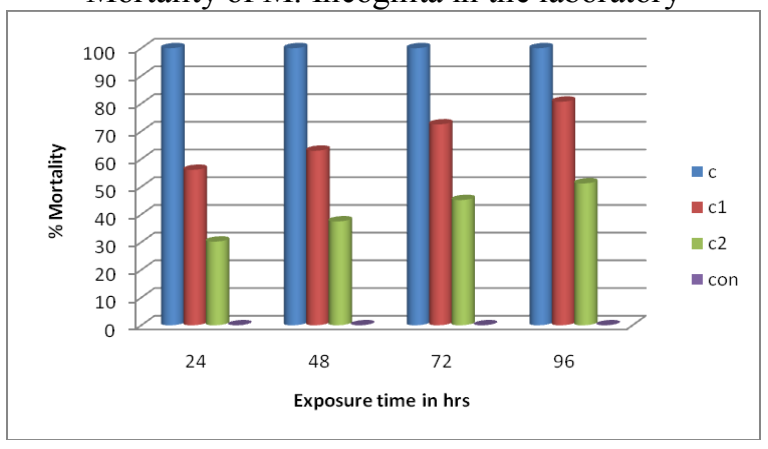

C- Crude extract, C1- crude extract diluted with $10 \mathrm{ml}$ of distilled water, C2- crude extract diluted with $20 \mathrm{ml}$ of distilled water, CON- control (distilled water).

corroborated that of Lata and Venapani (2010) who reported that the presence of secondary metabolites in water hyacinth shoots and rhizomes such as terpenoid, flavonoid and quinones have curative activity against several pathogens. Anuja and Satyawati (2007) also reported that plant extracts that contained phenolic compounds, alkaloids, glucosides and flavonoid have been found to be effective against M. incognita. The control recorded $0 \%$ juvenile mortality in all the exposure periods. The control been water is not toxic to nematodes and this resulted in zero mortality. 


\section{Conclusion}

The results obtained from the study indicated that water hyacinth have nematicidal property and hence can be used in the control of root knot nematode - M. incognita. The plant is available and cheap to obtain as it is a common weed growing over water bodies in Nigeria. It is suggested that further screen house and field trials be carried out before recommendations are made to farmers.

\section{Reference}

[1]. Adegbite, A. A. and S.O. Adesiyan (2005). Root extracts of plants to control root - knot nematode on edible Soybean. World Journal of Agricultural Science, 1 (1): 18-21

[2]. Anuja, B. and S. Saty awati (2007). Effect of some plant extracts on the hatch of M. Incognita eggs. Journal of Botany, 3: $312-316$

[3]. Atungwu, J. J. , A.A. Ademola and Aiyelagbe, I. O. O. (2009). Evaluation of organic. materials for inhibition of nematode reproduction in Soybean. African Journal of Crop Science, 17 (4): 167-173

[4]. Dareker, K.S. and N. L. Mhase (1988). Assessment of yield loss due to root knot nematode M. incognita race 3 in tomato, brinjal and bitter gourd. International Nematology Network Newsletter, 5, 7-9

[5]. Grodowitz, M. J. (1998). An active approach to the use of insect biological control for the management of non- native aquatic plants. Journal of aquatic plant management, 36: 5761-5763

[6]. Holm, L.G., Plucknett, D.L., Pancho, J.V., and Herberger, J.P. (1977). The world's worst weeds, Distribution and Biology, Honolulu, University press of Hawaii, pp72-77

[7]. IITA (2000). International Institute of Tropical Agriculture. Evaluation of plant based insecticides against field and storage pests of cowpea and soybean. Annual Report, Plant Health management Division, IITA, Ibadan, 33pp

[8]. Kristie, T. (2012). Plants, Garden Plants by name Water hyacinth.http://www.ehow.com/facts, 22/09/12, 9:22am

[9]. Lata, N. And Venapani, D. (2010). Preliminary phytochemical screening of Eichhornia crassipes: The world's worst aquatic weed. Journal of pharmacy Research, 3 (6): 1240-1242

[10]. Ploeg, M. (2002). Effect of neem (Azadirachta indica) formulations on the development of M. javanica in roots of tomato plants. Crop Protection, 26:530-534

[11]. Rao, M.S., Reddy, P. and Nagesh, M. (1998). Evaluation of plant based formulations of Trichoderma harizianum for the management of M. incognita in egg plant. Nematologia Mediterranea, 26: 59-62

[12]. Sofowora, A. (1993). Medicinal plants and Traditional medicine in Africa, $2^{\text {nd }}$ edition, spectrum books, Ibadan, Nigeria, pp289

[13]. Trease, G.E. and Evans, W.C. (1989). Pharmaognosy. $13^{\text {th }}$ edition, ELBS, Oxford University press, London, UK. Pp245-263

[14]. Umar, I. (2009). Effect of locust bean leaves and bark on the control of M. incognita on cowpea. Nigerian Journal of Tropical Agriculture, 11: 16-22

[15]. Whitehead, A. G. and Hemming, J.R. (1965). A comparison of some quantitative methods of extracting small vermiform nematodes from soil. Annals of Applied Biology, 55: 25-38

[16]. Wikipedia (2012). Ecchornia crassipes. http://en. Wikipedia.org/wiki/Ecchornia crassipes, 22/9/12,9:25am

[17]. Yudelman, M., A. Ratta and Nygaard, D. (1998). Pest management and Food Production: Looking to the future. Food, Agriculture and Environment. Discussion paper 25, International Food Policy Research Institute, USA, pp50. 